\title{
Portrayal of the Poor and Oppressed in the Select Novels of Charles Dickens and Mulk Raj Anand: A Comparative Study
}

\author{
A. Varalakshmi ${ }^{1}$, Dr. V. Sri Rama Murthy ${ }^{2}$, Dr.V.B.Chitra ${ }^{3}$ \\ ${ }^{I}$ Research Scholar, J N T University Anantapur, Anantapuram, A.P. \\ ${ }^{2}$ Assistantprofessor in English, Govt. Degree College, Naidupet, A.P. \\ ${ }^{3}$ Associateprofessor, JNT University Anantapur, Anantapuram, A.P.
}

\begin{abstract}
Charles Dickens, the greatest English novelist of the Victorian Era, attempts to draw the attention of his readers with the theme of poverty, one of the central problems in some of his novels. Mulk Raj Anand, an eminent Indian writer in English, is notable for his depiction of the lives of the poorer castes in traditional Indian society in his novels. The present article aims at making a comparative study of the poor and oppressed people in the novel Oliver Twist by Charles Dickens, and Untouchability by Mulk Raj Anand. The problem of poverty was very serious in English society of the late 19th century, and so Charles Dickens chose this theme as one of the central themes of some of his novels including Oliver Twist (1839). This novel represents the Victorian English society where the poverty is next to enormous wealth. Mulk Raj Anand's debut novel Untouchability exposes the oppression, injustice, exploitation to the whole community of the outcastes in India. This novel covers the span of a decade from 1930 to 1940 when poverty, slavery and the inhuman exploitation of the masses were at the peak. Both the writers in their novels focus on the poor, suffering and wretchedness of the poor. The outcastes are exploited by almost all on the economic level too. To both the writers, exploitation of man is immoral and impermissible, particularly the poor and the illiterate. Both of them depict the lifestyle of the poor and the upper class.
\end{abstract}

\section{INTRODUCTION}

Dickens was not only the first great urban novelist in England, but also one of the most important social commentators who used fiction effectively to criticize economic, social, and moral abuses in the Victorian era. Dickens showed compassion and empathy towards the vulnerable and disadvantaged segments of English society, and contributed to several important social reforms.

Dickens believed in the ethical and political potential of literature, and the novel in particular, and he treated his fiction as a springboard for debates about moral and social reform. In his novels of social analysis Dickens became an outspoken critic of unjust economic and social conditions.

Dickens was not the first novelist to draw attention of the reading public to the deprivation of the lower classes in England, but he was much more successful than his predecessors in exposing the ills of the industrial society including class division, poverty, bad sanitation, privilege and meritocracy and the experience of the metropolis. In common with many nineteenth-century authors, Dickens used the novel as a repository of social conscience

Mulk Raj Anand a socially committed novelist has produced a good deal of literature. He has written more than a dozen novels and about seventy short stories. He focused his attention on the sufferings, misery and wretches of the poor as a result of the exploitation of of the downtrodden classes of the Indian society. His themes mainly deals with the poverty, society hunger and exploitation.charless dickens is one of the greatest novelist in the English literatures. He wrote about the real world. He wrote about the poor people and social injustice

The theme of poverty remains on the central problems that Charles dickens focuses and attempts to draw attention to his readers. The problem of poverty becomes a serious social and economic burden of English society of the late $19^{\text {th }}$ century. The two writes are compared here as their themes were more related with the poor and oppressed people and social exploitation. Mulk Raj Anand was also called as Indian Charles dickens. Oliver Twist (1837-39), which represents a radical change in Dickens's themes, is his first novel to carry a social commentary similar to that contained in the subsequent Condition-of-England novels Dickens explores many social themes in Oliver Twist, but three are predominant: the abuses of the new Poor Law System the evils of the criminal world in London and the victimisation of children. The critique of the Poor Law of 1834 and the administration of the workhouse is presented in the opening chapters of Oliver Twist. Dickens gives the most uncompromising critique of the Victorian workhouse, which was run according to a regime of prolonged hunger, physical punishment, humiliation and hypocrisy Oliver fell on his knees, and clasping his hands 
together, prayed that they would order him back to the dark room—-that they would starve him—beat him—-kill him if they pleased — rather than send him away with that dreadful man [1]

In Oliver Twist Dickens presents a portrait of the macabre childhood of a considerable number of Victorian orphans. The orphans are underfed, and for a meal they are given a single scoop of gruel. Oliver, one of the oppressed children, dares to ask for more gruel and is severely punished.

The evening arrived; the boys took their places. The master, in his cook's uniform, stationed himself at the copper; his pauper assistants ranged themselves behind him; the gruel was served out; and a long grace was said over the short commons. The gruel disappeared; the boys whispered each other, and winked at Oliver; while his next neighbours nudged him. Child as he was, he was desperate with hunger, and reckless with misery. He rose from the table; and advancing to the master, basin and spoon in hand, said: somewhat alarmed at his own temerity: 'Please, sir, I want some more.' [2]

This scene, which has become "the most familiar incident in any English novel" strongly appealed to the Victorian conscience. Dickens challenged the Victorian idea of charity for the so-called "deserving poor". He showed persuasively that the workhouse was a failed attempt to solve the problem of poverty and unwanted children.

Anand's novel Untouchable expresses his great advocacy of the marginalized and defenceless against their age long humiliation, persecution and oppression. Anand himself observes Great author is to highlight the cause of the dumb and the deserted, the lowly and the lost of an adverse society. The author also flings a harsh irony on the snobbery and hypocrisy, ostentation and fabrication of the aristocratic people who, sometimes One of the prime concerns of a stoop low to achieve the end. A writer, the prince of the pen, is the true voice of the million mass particularly of the untouchable and the vulnerable victimized by undeserved tyranny and injustice from the time immemorial. And this is what prompted Mulk Raj Anand to present the deplorable description of the destitute

In this article there were a lot of similarities in the works of Charles dickens oliver twist and Mulk Raj Anand untouchable .First if we go for the work of Charles dickens. Charles Dickens in this novel Oliver Twist depict English society of Victorian age which is full of contrasts where the poverty is next to snornious wealth, and where spiritual richness is often overshadowed by the material desperate social portions of the characters of novels.dickens pores a question whether poverty is really a sinn or something really bad that make people fall lower and lower in the social ladder or probably it is just a poor material portion of individuals.

In the novel untouchable by Mulk raj anand covers the san from 1930 to 1940 when poverty slavers and the inhuman exploilation of the masses were at the peak. In this Novel untouchable by Mulk raj anand the characters in this novels belongs to downtreden society. There was a poverty and slavery in this Novel,the authorisation of high class society on low class society, hunger and poverty is potrayed in this Novels.So, in there two novel both the writers used the themes of poverty, hunger, social status and human exclopitation .

Charles dickens depicts the opprersive nature of the $19^{\mathrm{th}}$ century society and subjection of the poor and poverty.while Mulk raj anand depicted the poor and oppressive nature of $21^{\text {st }}$ century society and its subjection of the poor and poverty. Both the novels oliver twist and untouchable well illustrate the situation and condition of the lower class Juxtapore against the lavish liver of middle classes and the aristocracy.In oliver twist oliver is the protagonist, he is an orphan. Oliver twist and his companions suffered the tortures of slow staruation for many days.the powerful pathor and visual imagery which dicken user in deserileing Oliver is a martuful creation to intensify the gravity of circumstances in which Oliver finds himself. The staruation of the poor at athe work houses was also a reflection of the hunger encountered by the paupers outside the poor work houses.

In untouchable Bakha is the protagonist. Anand is the first Indian novelist to have depicted in the novel from the stigma of this eveil which isolates a man from his own society. The character in his novels belongs to the down trodelen society. The characters are normal, simple, credible human being unaware of their social conditions.Bhaka shouts for foods and begs for food.The woman comes out and throws a chapatti for him, he suffered with hunger all the day. M.K Naïk writes "Untouchable is a scathing incident of Hindu society and irony is the weapon of this indictment"[3]

There were many situations in oliver twist where oliver was insulted many times, from his birth, when oliver goes to the workhouse, he is introduced to ten fat gentleman and one who was particularly fat with very round red face. The fat gentle men are juxtaposed against the children at the poor houses who were starved as evidenced by the scene in which the older children forced oliver to ask for more food. In the novel it is stated that the immater were fed on the small quantities of oatmeal, three meals of thin gravel a day and half a roll on Sundays. The same way untouchable by Mulk raj anand also depicts the related circumstances, Bakha a sweeper boy and a latrine clean starts his day welcomed by the abuses of his latrines with a brush and bucket.After cleaning roads and toilets in house, he goes to an alley nearby to beg for food. When bakha returns home, he tells his father They think we are mere dirt because we clean their dirt" [4] 
He starts shouting or food but nobody responds tired of the hectic schedule he sleeps on the wooden platform in front of a house.The woman comes out of the house on the call of a sadhu. She shouts at Bakha for polluting her house. She asks him to clean the drain to get a piece of bread. Mean while a woman from neighbouring house gives him a chapatti .Mulk raj anand in his article "The source of potest in my Novels" say I wished to create the folk, the lumpens and the suppressed, oppressed, repressed, those who have seldom appeared in our literature"[5]

In oliver twist the poor were actually oppressed and those who were not living in the work house were forced to work and they could no longer be provided with any aid.In Victorian age the authorities believed that the paupers were lazy and idle, yet hey failed to understand that they were poor because of lack of employment and if they did final any work at all, it was always low paying petty work like sweeping and repairing roads.Even though the poor laws were snacted to arrist the poor, they did nothing to change their plight or improve their situation. The poor were furthered exploited by physical and emotional abuses. and takes him to his home lifting on his hand. The thankless mother of the child shouts at him for defiling her house. For the work he did they throw the bread of slice on him as they do to animals so they workhard, they were ill treated due to their poverty, hunger and low_class. Oh! You eater of masters what have you done ?....Give me my child ...you have defiled the houses besides wounding my son"[6] In case of Mulk raj untouchable in period from 1930 to 1960 's in India the poor end lower cartes were treated very badly, there were some invidents that happend in a day to Bakha. He receives a slap from the high cart Brahmin for defiling him by his touch makes him aware of his true identity. An other incident he faces at another moment of humiliation at the steps of the temple that increases the rage of his soul. Once when he saved the child from accident

In untouchable the themes of exploitation are best expressed through the character of sohini Bakha's sister. She not only excmplifier caste expoitation but also six exploitation.Gulabo a washer woman, a caste superior to other cartes exploits sohini, she being of the low carte among he outcartes would naturally be looked down upon by Gulabo. She becomes the victim of sexual exploitation due to here carte and poverty.

Dickens successfully portrays the child exploitation in Oliver twist. He potrays it as the abuse of them in $19^{\text {th }}$ century Britian. Most of there children are orphans and also members of the low class, therefore they were economically desparate and they were forced to endure by means of survivial even if it meant accepting maltreatment. In oliver twist olivers feels alone, he dislikes being alone and having no body to care for him, where as in untouchable Bakha also feels alone though he has a father lakhe who is not piety enough towards his son and daughter and always abuses him with his bad words.

Dickens showed compassion and empathy towards the vulnerable and disadvantaged segments of English society, and contributed to several important social reforms. Dickens's deep social commitment and awareness of social ills are derived from his traumatic childhood experiences when his father was imprisoned in the Marshallese Debtors' Prison under the Insolvent Debtors Act of 1813, and he at the age of twelve worked in a shoe-blacking factory In his adult life Dickens developed a strong social conscience, an ability to empathise with the victims of social and economic injustices

Mulk Raj also have the child hood experiences which he portrayed in untouchable Bakha's character is modelled after one of Anand's childhood friends, who was humiliated by his own mother for being a sweeper boy but whom Anand adored as a hero. Anand could never forget that sweeper boy and the insult and humiliation that he received by Anand's family. He gave voice to his views against the exploitation of a sweeper-boy through the character of Bakha in his very first novel Untouchable.

Dickens explores many social themes in Oliver Twist, but three are predominant: the abuses of the new Poor Law system, the evils of the criminal world in London and the victimisation of children... Dickens gives the most uncompromising critique of the Victorian workhouse, which was run according to a regime of prolonged hunger, physical punishment, humiliation and hypocrisy. Mulk Raj also explores social themes in untouchable he focused his attention on the sufferings, misery and wretchedness of the poor as a result of the exploitation of the downtrodden class of the Indian society. Religious hypocrisy, feudal system, East-West encounter, the place of woman in the society, superstitions, poverty, hunger and exploitation are his common themes.

In Untouchable Bakha suffers without any fault of his own. The slap he receives from the high caste Brahmin for defiling him by his touch makes him aware of his true identity. Soon after this he faces another moment of humiliation at the steps of the temple that increases the rage in his soul. But the molestation of his sister by the priest turns him violent to which he reacts aggressively. But his hereditary serfdom acts as a handicap to his spontaneous rebellion. In both the cases oliver in oliver twist and bakha in untouchability become rebellious towards the attitude of their superiors. He is simultaneously an exploited person and a rebel. $\mathrm{He}$ is scapegoat of the rigid caste system. Injustice inflicted upon him makes him rebellious. Excessive buses and insult makes him think about retaliation. At such moments he feels like a tiger at a bay. Saros Cowasjee in her book So Many Freedoms rightly says, But he is a tiger in a cage, securely imprisoned by the conventions his superiors have built up to protect themselves against the fury of those whom they exploit. [7] 


\section{CONCLUSION}

In the comparative study of both the novels oliver twist by Charles dickens and untouchable by Mulk Raj Anand there were a lot of similarities related to the poverty and oppression. Though the countries were different, traditions were different, culture changes but the poverty remains the same. Both the protagonists Oliver Twist and Bakha suffered throughout the novel because of poverty and oprresion. There were many similarities in writings of both the authors.

\section{WORKS CITED}

[1] Oliver Twist. Oxford: Oxford University Press, 1999.

[2] Ruth Richardson "poverty and working class", The novel 1832-1880, British Library

[3] Naik M.K "A History of Indian English lit "page-155

[4] Anand M. R "Untouchable "Penguin books India, 1993 page -70

[5] Mulk Raj Anand "The Source of Protest in my Novels "Atlantic publishers \&Distributors, ISBN 817156-855-6S

[6] Anand M. R "Untouchable "Penguin books India, 1993 page -70

[7] So Many Freedoms: A study of the major fiction of Mulk Raj Anand by Saros Cowasjee, New yark and Oxford University press, 1977 